\title{
Zbywanie roszczeń o naprawienie szkody wyrządzonej czynem niedozwolonym. Ratio legis, treść normatywna oraz przyszłość uregulowania art. 449 k.c.
}

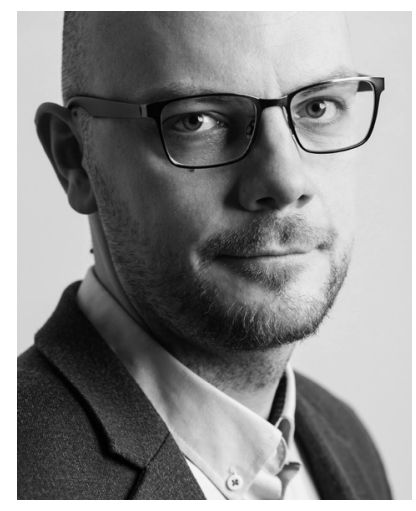

\section{Radostaw Strugata}

Adiunkt w Instytucie Prawa Cywilnego na Wydziale Prawa, Administracji i Ekonomii Uniwersytetu Wrocławskiego, członek kolegium redakcyjnego „Wroctaw Review of Law, Administration and Economics", stypendysta Instytutu Maxa Plancka w Hamburgu oraz Uniwersytetu w Bergamo, w latach 2013-2015 członek zespołu problemowego Komisji Kodyfikacyjnej Prawa Cywilnego.

$\triangle$ radoslaw.strugala@uwr.edu.pl https://orcid.org/0000-0001-5770-770X

\section{Assignability of Claims for Personal Injuries Caused by Torts. Ratio Legis, Present and Future of the Regulation}

\begin{abstract}
The aim of the paper is to present an alternative interpretation of the article 449 of the Polish Civil Code. In contrast to the most common, literal interpretation thereof, the paper offers a purposive interpretation taking into account ratio legis of the provision at stake. This tool enables to cast away some interpretative doubts which are constantly raised in the literarure. For inastance, it leads to the conclusion that the acknowledgement of debt which (according to the article 449 of the Polish Civil Code) renders the claims for damages assignable shall be limited to the acknowledgement in the strict meaning of the term, that is to the acknowledgement understood as a contract between creditor and debtor, and shall determine a sum of the acknowledged claim. The paper concludes that the article 449 of the Polish Civil Code, thanks to its purposive interpretation, may effectively protect assignors from assigning their claims for damages for the price which is far lower than the value of damages to which the assignor was entitled. This conclusion put in the context of ongoing works on the new law regulating the compensation agencies makes the article 9 of this law (which exludes the possibility of assignement of claims for damages) redundant.
\end{abstract}

Słowa kluczowe: wierzytelności odszkodowawcze, przelew, szkoda na osobie

Key words: assignment, personal injuries, claims for damages https://doi.org/10.32082/fp.v4i54.216 


\section{Problemy interpretacyjne art. 449 k.c. i ich aktualność}

Przepis art. 449 k.c. stanowi, że roszczenia przewidziane w art. 444-448 nie mogą być zbyte, chyba że są już wymagalne i zostały uznane na piśmie albo przyznane prawomocnym orzeczeniem. Jako taki przepis ten reguluje problematykę zbywania roszczeń przewidzianych w art. 444-448 k.c., tj. zarówno majątkowych, jak i niemajątkowych roszczeń o naprawienie szkody na osobie wyrządzonej czynem niedozwolonym (deliktem). Lege non distinguente do roszczeń tych należy zaliczyć roszczenie o zadośćuczynienie, roszczenia o zasądzenie odpowiedniej sumy pieniężnej na wskazany przez poszkodowanego cel społeczny, a także roszczenia o rentę oraz o odszkodowanie jednorazowe ${ }^{1}$. W zakresie wszystkich tych typów roszczeń ograniczenia wyrażone w art. 449 k.c. odnoszą się przy tym, rzecz jasna, do uprawnionych będących osobami bezpośrednio poszkodowanymi czynem niedozwolonym (zob. art. 444 i 445 k.c.), jak i osób, których roszczenia odszkodowawcze są konsekwencją uszczerbków doznanych pośrednio - na skutek śmierci bliskiego w wyniku deliktu (zob. art. 446 k.c.) $)^{2}$. Tyle o uregulowaniu art. 449 k.c. wiadomo na pewno. Jego brzmienie pozostaje jednak na tyle ogólne, że jego wykładnia może prowadzić do całego szeregu wątpliwości. W moim przekonaniu wiele $\mathrm{z}$ nich nie zostało dotąd rozwianych ani w nauce, ani w judykaturze. Niewykluczone, że jest tak dlatego, że przepisowi art. 449 k.c. poświęca się w doktrynie stosunkowo niewiele uwagi.

Wątpliwości dotyczące wykładni omawianego przepisu mogą generować daleko idące rozbieżności w orzecznictwie, rodząc niepewność na rynku obrotu wierzytelnościami odszkodowawczymi. Jest to oczywiście zjawisko niepożądane. Samo w sobie wystarczająco uzasadnia ono konieczność przeprowadzenia bliższej analizy treści normatywnej art. 449 k.c. Obecnie za potrzebą podjęcia takiej analizy przemawia dodatkowo kształt toczących się od niedawna

1 Z. Masłowski (w:) Z. Resich i in. (red.), Kodeks cywilny. Komentarz, t. 2, Warszawa 1972, s. 1132; M. Safjan (w:) K. Pietrzykowski (red.), Kodeks cywilny, t. 1: Komentarz. Art. 1-449', Warszawa 2015, s. 1533.

2 Por. A. Śmieja (w:) A. Olejniczak (red.), System prawa prywatnego, t. 6, Warszawa 2014, s. 772. prac nad rozwiązaniami legislacyjnymi dotyczącymi świadczenia usług w zakresie dochodzenia roszczeń odszkodowawczych. W ich ramach żywo dyskutowany jest temat ograniczenia zbywalności roszczeń odszkodowawczych. W art. 9 projektu Ustawy o świadczeniu usług w zakresie dochodzenia roszczeń odszkodowawczych wynikających z czynu niedozwolonego ${ }^{3}$ zaproponowano rozwiązanie, zgodnie z którym „[n]ie można przenieść wierzytelności z tytułu czynów niedozwolonych na doradcę $e^{4}$ lub osobę trzecią".

Zgodnie z założeniem projektodawców zakaz cesji wierzytelności odszkodowawczych ma stanowić jedno z narzędzi urzeczywistnienia ogólnego celu projektowanej ustawy, jakim jest zwiększenie zakresu ochrony osób, które poniosły szkodę w wyniku czynów niedozwolonych i decydują się na skorzystanie przy dochodzeniu roszczeń odszkodowawczych z usług tzw. kancelarii odszkodowawczych. Jak przyjęto w uzasadnieniu projektu, wprowadzenie do ustawy zakazu cesji wierzytelności z czynów niedozwolonych uniemożliwiłoby obejście przepisów ustawy poprzez zbycie wierzytelności. Można się domyślić, że chodzi o zagrożenie związane ze zbyciem wierzytelności zarówno na rzecz przedsiębiorcy nieobjętego reżimem ustawy ${ }^{5}$, jak i na rzecz samego tzw. doradcy, który - zamiast pośredniczyć $\mathrm{w}$ dochodzeniu roszczeń zgodnie z założeniami ustawy i z zastosowaniem wyrażonych w niej mechanizmów chroniących poszkodowanego - sam nabywałby od niego wierzytelność odszkodowawczą za cenę niższą od zasądzonego ostatecznie odszkodowania ${ }^{6}$.

3 Zob. Uchwała Senatu Rzeczypospolitej Polskiej z dnia 26 października 2018 r. w sprawie wniesienia do Sejmu projektu ustawy o świadczeniu usług w zakresie dochodzenia roszczeń odszkodowawczych wynikających z czynu niedozwolonego, http://orka.sejm.gov.pl/Druki8ka.nsf/ Projekty/8-020-1011-2018/\$file/8-020-1011-2018.pdf (dostęp: 11.01.2020).

4 Stosownie do art. 2 wspomnianego projektu, ilekroć w ustawie jest mowa o doradcy, rozumie się przez to przedsiębiorcę wykonującego działalność gospodarczą w zakresie dochodzenia roszczeń odszkodowawczych.

5 Tak w uzasadnieniu projektu Ustawy o świadczeniu usług w zakresie dochodzenia roszczeń odszkodowawczych wynikających z czynu niedozwolonego, s. 4.

6 Praktyka polegająca na nabywaniu wierzytelności od mających słabą orientację i niewielkie doświadczenie w dochodze- 
Niewykluczone, że zakaz cesji wierzytelności odszkodowawczych z tytułu czynów niedozwolonych rzeczywiście mógłby zaradzić pewnym zagrożeniom związanym z funkcjonowaniem rynku usług polegających na dochodzeniu roszczeń odszkodowawczych. Jednak taki generalny zakaz niósłby ze sobą zbyt daleko idące ograniczenia dla obrotu wierzytelnościami. Z punktu widzenia całego systemu prawa prywatnego ustawa regulująca świadczenie usług związanych $\mathrm{z}$ pośredniczeniem $\mathrm{w}$ dochodzeniu roszczeń odszkodowawczych nie jest z pewnością aktem prawnym odpowiednim dla wyrażenia tego rodzaju ograniczenia. Jest symptomatyczne, że projektodawcy pominęli w ogóle fakt obowiązywania art. 449 k.c. W pierwszej kolejności należy rozważyć, czy ten ostatni przepis nie stanowi aby odpowiedniego zabezpieczenia przed zagrożeniami dostrzeganymi przez autorów projektu, czyniąc rozwiązanie przewidziane w art. 9 projektu zbędnym 7 . Pamiętając o tym, że art. 449 k.c. odnosi się wyłącznie do wyrządzonych czynem niedozwolonym szkód na osobie, można się też zastanowić, czy dla zabezpieczenia poszkodowanych przed zbywaniem roszczeń odszkodowawczych poniżej wartości należnego im odszkodowania nie byłoby celowe rozszerzenie zakresu zastosowania art. 449 k.c. na roszczenia o naprawienie szkód na mieniu ${ }^{8}$. Odpo-

niu roszczeń osób poszkodowanych deliktem jest niezwykle rozpowszechniona i, obok pośrednictwa w dochodzeniu roszczeń odszkodowawczych, stanowi jeden ze sposobów funkcjonowania tzw. kancelarii odszkodowawczych. Kancelarie te, z uwagi na swoje doświadczenie i świadomość nierzadkiej praktyki zaniżania odszkodowania przez ubezpieczycieli liczących na brak determinacji poszkodowanego, który zamiast odwoływać się w postępowaniu likwidacyjnym lub wnosić powództwo poprzestaje na wypłacie zaoferowanej przez zakład ubezpieczeń, są zwykle skuteczniejsze i ostatecznie udaje im się uzyskać większe kwoty odszkodowań.

7 Trzeba podkreślić, że na obecnym etapie prac legislacyjnych słusznie wycofano się z rozwiązania zaproponowanego w art. 9 projektu. Niepewne pozostają jednak dalsze losy projektu, z myślą o których prowadzone są dalsze rozważania.

8 Takie, prima facie trafne, rozwiązanie sugeruje - jak się wydaje - M. Kaliński w wywiadzie udzielonym na łamach „Gazety prawnej” (zob. Bezgotówkowa likwidacja szkód trudniejsza przez zakaz cesji wierzytelności, „Gazeta Prawna” 14.11.2018). wiedź na te pytania nie jest możliwa bez szczegółowej wykładni art. 449 k.c. pozwalającej ustalić, jaką treść normatywną przepis ten ma de lege lata.

\section{Sporne wątki wykładni art. 449 k.c.}

Jak powiedziano wyżej, art. 449 k.c. rodzi wiele wątpliwości interpretacyjnych. Przepis stanowi, że roszczenia należące do wskazanej w nim grupy stają się zbywalne jedynie wówczas, gdy są wymagalne, a jednocześnie zostały uznane przez dłużnika odszkodowawczego na piśmie albo przyznane prawomocnym orzeczeniem. Warunki te muszą być spełnione łącznie. Drogę do zbywalności wymagalnego roszczenia odszkodowawczego otwiera więc m.in. uznanie go na piśmie. Sporne jest przy tym, czy skutek taki jest aktualny wyłącznie w razie uznania właściwego ${ }^{9}$, czy za wystarczające należy uznać uznanie niewłaściwe ${ }^{10}$, a także czy skutek ten zależy od ustalenia w treści uznania wysokości roszczenia ${ }^{11}$. Wątpliwości powstają także przy wykładni przesłanki wymagalności roszczenia odszkodowawczego, od której spełnienia zależy jego zbywalność.

Przede wszystkim jednak niejasny pozostaje sam zakres zastosowania art. 449 k.c. Przepis stanowi, że roszczenia przewidziane $\mathrm{w}$ art. 444-448 nie mogą być zbyte, chyba że są już wymagalne i że zostały uznane na piśmie albo przyznane prawomocnym orzeczeniem. Dotyczy on zatem wyłącznie zbywania wskazanych w nim roszczeń, przez które należy rozumieć przeniesienie tych roszczeń przez uprawnionego na inny podmiot w drodze czynności prawnej ${ }^{12}$.

9 Tak M. Safjan (w:) Kodeks cywilny..., dz. cyt., s. 1597.

10 Tak A. Olejniczak (w:) A. Kidyba (red.), Kodeks cywilny. Komentarz, t. 3, Warszawa 2014, s. 595; P. Sobolewski (w:) K. Osajda (red.), Kodeks cywilny. Komentarz, t. 3A, Warszawa 2018, s. 894.

11 Tak M. Safjan (w:) Kodeks cywilny..., dz. cyt., s. 1597; P. Sobolewski (w:) Kodeks cywilny..., dz. cyt., s. 894; M. Wałachowska (w:) M. Habdas, M. Fras (red.), Kodeks cywilny. Komentarz, t. 3, Warszawa 2018, s. 721; odmiennie np. A. Śmieja (w:) System prawa prywatnego, dz. cyt., s. 772.

12 Jest oczywiste, że nie znajduje on zastosowania do problematyki przeniesienia tych roszczeń w konsekwencji zdarzeń innych niż czynność prawna, na przykład w następstwie dziedziczenia (por. wyr. SN z 29.7.1970, II CR 307/70, Legalis; A. Olejniczak (w:) Kodeks cywilny..., dz. cyt., s. 595; 
Przewidziane w art. 449 k.c. ograniczenie zbywalności roszczeń, o których mowa w tym przepisie służy ochronie poszkodowanych przed ryzykiem zbycia spornych (nieokreślonych) co do wysokości roszczeń odszkodowawczych w zamian za świadczenie (cenę) nieodpowiadające ich realnej wartości czyły skutek przelewu) prima facie wydaje się więc nie podlegać ograniczeniom wyrażonym w art. 449 k.c. W literaturze kwestia ta nie była dotąd szczegółowo analizowana. Dominuje wprawdzie pogląd zakładający nieważność umów zobowiązujących do przelewu niewymagalnych, nieuznanych na piśmie lub nieprzy-

\section{Przewidziane w art. 449 k.c. ograniczenie} zbywalności roszczeń służy ochronie poszkodowanych przed ryzykiem zbycia spornych (nieokreślonych) co do wysokości roszczeń odszkodowawczych w zamian za świadczenie (cenę) nieodpowiadające ich realnej wartości.

Dosłownie odczytany przepis art. 449 k.c. ogranicza możliwość zbywania roszczeń o naprawienie szkód na osobie. Takie ograniczenie jest w istocie rzeczy ograniczeniem dopuszczalności przelewu jako czynności prawnej rozporządzającej służącej zbywaniu wierzytelności. Przelew mający za przedmiot roszczenia przewidziane w art. 444-448 k.c., które nie są wymagalne i jednocześnie nie są stwierdzone prawomocnym wyrokiem lub uznane na piśmie, jest więc umową nieważną ${ }^{13}$. Niejasne pozostaje natomiast, w jaki sposób treść art. 449 k.c. wpływa na czynności prawne zobowiązujące do przelewu. Z jego literalnego brzmienia nie wynika, by wyrażone w nim ograniczenie rozciągało się na czynności prawne zobowiązujące do przelewu. Sama umowa zobowiązująca do przelewu (np. umowa sprzedaży wierzytelności, w której strony - stosowanie do art. $510 \$ 1$ k.c. - wyłą-

M. Safjan (w:) Kodeks cywilny..., dz. cyt., s. 1532). Niektóre spośród roszczeń przewidzianych w art. 444-448 k.c. zostały jednak poddane ograniczeniom podobnym do tych ujętych w komentowanym przepisie także w zakresie dziedziczenia (zob. art. $445 \$ 3$ i 448 zd. 2).

13 Zob. wyrok Sądu Apelacyjnego w Białymstoku z dnia 15 listopada 2013 r., I ACa 497/13, Legalis. znanych orzeczeniem roszczeń z art. 444-448 k.c. ${ }^{14}$. Teza ta nie jest jednak przez przedstawicieli doktryny uzasadniana. W świetle brzmienia art. 449 k.c. jej weryfikacja wymaga, w moim przekonaniu, sięgnięcia do dyrektyw wykładni funkcjonalnej.

Podobnie bez sięgnięcia do argumentów natury funkcjonalnej nie sposób rozstrzygnąć, czy zbywalność roszczeń, o których mowa w art. 449 k.c., przepis też uzależnia od uznania właściwego czy także niewłaściwego. Zakaz wykładni homonimicznej i dyrektywa lege non distinguente każe raczej przyjąć, że w świetle brzmienia art. 449 k.c. o zbywalności wskazanych w nim roszczeń odszkodowawczych może decydować fakt dokonania przez dłużnika odszkodowawczego zarówno uznania właściwego, jak i niewłaściwego. Wszak na gruncie art. 123 k.c. pod pojęciem uznania rozumie się zarówno uznanie właściwe, jak i niewłaściwe. Akceptując pogląd ograniczający zbywalność tych roszczeń do sytuacji, gdy zostały one objęte

14 Tak wyraźnie A. Śmieja (w:) System prawa prywatnego, dz. cyt., s. 772; por. K. Mularski (w:) M. Gutowski (red.), Kodeks cywilny. Komentarz, t. 1, Warszawa 2016, s. 1878; A. Olejniczak (w:) Kodeks cywilny..., dz. cyt., s. 594. 
uznaniem właściwym, należałoby go więc uzasadnić, odwołując się do pozajęzykowych dyrektyw wykładni.

Moim zdaniem większość zasygnalizowanych właśnie kwestii spornych można rozstrzygnąć, odwołując się do ratio legis art. 449 k.c. Cel tej regulacji jest wyjątkowo rzadko przywoływany w rozważaniach doktryny. Skoro zaś, jak pokazują dotychczasowe uwagi, poprzestanie na jej literalnym brzmieniu nie prowadzi do zadowalających rezultatów, w dalszej części opracowania wypadnie przybliżyć trafnie ujęte niegdyś przez Zbigniewa Masłowskiego motywy jej wprowadzenia.

\section{Ratio legis art. 449 k.c.}

Za motyw ograniczenia zbywalności roszczeń przewidzianych w art. 449 k.c. należy uznać ochronę poszkodowanych przed ryzykiem zbycia (sprzedaży) spornych (nieokreślonych) co do wysokości roszczeń odszkodowawczych w zamian za świadczenie (cenę) nieodpowiadające ich realnej wartości ${ }^{15}$. Trzeba się zgodzić, że w przypadku poszkodowanych, nierzadko znajdujących się w złej sytuacji finansowej, ryzyko zbycia roszczeń za kwotę niższą od wartości odszkodowania, które zostanie ostatecznie przyznane w wyroku, jest dosyć duże. Niewykluczone, że współcześnie, w dobie rozwiniętego rynku obrotu wierzytelnościami, jest ono większe niż w dacie uchwalenia komentowanego przepisu. Wydaje się też, że przepisy ogólne (np. art. $58 \$ 2$ czy 388 k.c.) nie chronią przed takim ryzykiem w sposób dostateczny. Rozwiązanie przewidziane w art. 449 k.c., choć świadczy o mocno paternalistycznym podejściu ustawodawcy, trudno więc uznać za nieracjonalne ${ }^{16}$.

Nie byłoby natomiast celowe doszukiwanie się jakiejkolwiek symetrii w zakresie celu uregulowania art. 449 k.c. i 445 k.c. Ten ostatni przepis wprowadza ograniczenia dziedziczności roszczeń o naprawienie szkody niemajątkowej (krzywdy) spowodowanej czynem niedozwolonym z powodów znacznie różniących się od tych będących źródłem ograniczeń zbywalności

15 Tak, trafnie, Z. Masłowski (w:) Kodeks cywilny..., dz. cyt., s. 1130.

16 Zob. jednak jego krytykę, odnoszącą się do zbywalności roszczeń o naprawienie szkody majątkowej, sformułowaną przez K. Mularskiego (w:) Kodeks cywilny..., dz. cyt., s. 1878. roszczeń odszkodowawczych z art. 449 k.c. Z uwagi na te różnice nie byłoby wskazane dążenie przy wykładni obu przepisów do ujednolicenia kształtu przesłanek określonych w obu $\mathrm{z}$ nich ${ }^{17}$.

Ratio legis art. 449 k.c. odpowiada motywom art. 9 projektu Ustawy o świadczeniu usług w zakresie dochodzenia roszczeń odszkodowawczych wynikających z czynu niedozwolonego, dlatego też uwzględniająca tę ratio legis wykładnia pierwszego z wymienionych przepisów przemawia przeciwko wprowadzeniu do polskiego systemu prawnego drugiego $\mathrm{z}$ nich.

Łatwo zauważyć, że zaakceptowane wyżej motywy legislacyjne są zbieżne $\mathrm{z}$ ratio legis projektowanego art. 9 Ustawy o świadczeniu usług w zakresie dochodzenia roszczeń odszkodowawczych wynikających z czynu niedozwolonego. Jako takie nie tylko powinny one wyznaczać kierunek wykładni art. 449 k.c., ale stanowić mogą ważny argument $\mathrm{w}$ dyskusji nad celowością regulacji zaproponowanej w art. 9 projektu. Skoro cele zakładane przez projektodawców można skutecznie osiągać za pomocą odpowiednio interpretowanego ograniczenia zbywalności roszczeń odszkodowawczych wyrażonego w art. 449 k.c., całkowite jej wyłączenie (na wzór art. 9 projektu) należy uznać za zbyt daleko idące. Potencjalnie argumentem przemawiającym na rzecz jakichkolwiek zmian legislacyjnych w zakresie zbywalności roszczeń odszkodowawczych mogłaby się ewentualnie okazać potrzeba rozszerzenia zakresu zastosowania art. 449 k.c. na roszczenia o naprawienie szkody na mieniu. O tym, czy taka potrzeba rzeczywiście istnieje, wypadnie zdecydować w podsumowaniu tego opracowania. Sformułowanie takich wniosków zostanie poprzedzone szczegółową

17 Potrzebę jednolitej wykładni uregulowania obu przepisów dostrzega A. Śmieja (w:) Studia prawa prywatnego, dz. cyt., s. 772. Autor nie uwzględnia jednak okoliczności, że cele stojące za uregulowaniem art. 449 k.c. nie są aktualne w odniesieniu do art. 445 k.c., w przypadku którego np. wymaganie określenia wysokości roszczenia nie jest konieczne. Co do ratio legis art. 445 k.c. zob. przekonujące uwagi A. Szpunara, O przejściu na spadkobierców roszczeń z tytułu zadośćuczynienia, „Rejent” 2002, nr 9, s. 21, gdzie powołano się na ratio legis przepisu art. 445 k.c., która zakłada, że dziedziczność roszczenia o zadośćuczynienie powinna występować wyłącznie wtedy, gdy spadkodawca miał świadomość swojego roszczenia i liczył się z wejściem zadośćuczynienia do jego majątku. 
wykładnią art. 449 k.c. W jej ramach kolejne, zasygnalizowane wcześniej, kwestie sporne zostaną zestawione z zakreślonym wyżej ratio legis tego uregulowania.

\section{Ograniczenie dopuszczalności przelewu czy także umów zobowiązujących do przelewu?}

Jak zauważono wyżej, wykładnia gramatyczna art. 449 k.c. prowadzi do wniosku, że przepis ten ogranicza dopuszczalność zawierania umów przelewu określonych w nim roszczeń odszkodowawczych. Umowy przelewu mające za przedmiot roszczenia przewidziane w art. 444-448 k.c., które nie są wymagalne i jednocześnie nie są stwierdzone prawomocnym wyrokiem lub uznane na piśmie, należy w jego świetle uznać za nieważne. Podkreślono też, że z literalnego nieważna, jeśli została zawarta bez ziszczenia przesłanek, o których mowa w art. 449 k.c., jest możliwy do obrony tylko w razie spełnienia jednego $\mathrm{z}$ dwóch następujących założeń. Po pierwsze, umowę zobowiązującą (np. umowę sprzedaży czy darowizny, o której mowa w art. 510 k.c.) do przeniesienia roszczeń odszkodowawczych niemających cech, o których mowa w art. 449 k.c., można by uznać za nieważną na podstawie art. 387 k.c., przyjmując, że jest to umowa o świadczenie niemożliwe. Po drugie, umowę zobowiązującą do przelewu można uznać za nieważną, z uwagi na jej sprzeczność z ustawą (zob. art. $58 \$ 1$ i $353^{1}$ k.c.), gdyby przyjąć, że art. 449 k.c. - wbrew dosłownemu brzmieniu - nie wprowadza ograniczeń wyłącznie w zakresie zbywania wskazanych w jego treści roszczeń, ale formułuje również dalej idący zakaz. Chodzi o zakaz zawierania

\section{Ratio legis art. 449 k.c. odpowiada motywom}

art. 9 projektu Ustawy o świadczeniu usług w

zakresie dochodzenia roszczeń odszkodowawczych

wynikających z czynu niedozwolonego, dlatego

też uwzględniająca tę ratio legis wykładnia

pierwszego $\mathrm{z}$ wymienionych przepisów

przemawia przeciwko wprowadzeniu do

polskiego systemu prawnego drugiego $\mathrm{z}$ nich.

brzmienia art. 449 k.c. nie wynika wcale, by wyrażone w nim ograniczenie rozciągało się na czynności prawne zobowiązujące do przelewu. Sama umowa zobowiązująca do przelewu (np. umowa sprzedaży wierzytelności, w której strony - stosownie do art. $510 \$ 1$ k.c. - wyłączyły skutek przelewu) prima facie wydaje się więc nie podlegać ograniczeniom wyrażonym w art. 449 k.c., co oznaczałoby, że pozostaje ważna, nawet jeśli została zawarta wbrew tym ograniczeniom.

W moim przekonaniu wniosek przeciwny, oznaczający, że sama umowa zobowiązująca do przelewu jest umów zobowiązujących do rozporządzania takimi roszczeniami, jeśli nie są one wymagalne oraz uznane na piśmie lub przyznane orzeczeniem. Moim zdaniem druga z postawionych właśnie tez jest prawidłowa.

Art. 449 k.c. - wbrew dosłownemu brzmieniu - nie wprowadza ograniczeń wyłącznie w zakresie zbywania (przelewu) wskazanych w jego treści roszczeń, ale formułuje również dalej idący zakaz - zaciągania zobowiązań do ich zbywania (np. zawierania umów sprzedaży czy darowizny wierzytelności odszkodowawczych). 
Co do pierwszej z nich należy przyjąć, że jakkolwiek omawiany przypadek dałoby się uznać za postać tzw. konstrukcyjnej niemożliwości świadczenia ${ }^{18}$, zastosowanie art. 387 k.c. jest wykluczone z uwagi na brak możliwości uznania, że niemożliwość taka ma cha- z art. 510 k.c. - nie wywoływałyby one skutków rozporządzających, a jedynie skutki obligacyjne. Takie skutki obligacyjne z powodu ograniczeń wyrażonych w art. 449 k.c. nie mogłyby zostać zrealizowane. Innymi słowy, wynikające $\mathrm{z}$ art. 449 k.c. wyłącze-

\section{Art. 449 k.c. - wbrew dosłownemu brzmieniu -} nie wprowadza ograniczeń wyłącznie w zakresie zbywania (przelewu) wskazanych w jego treści roszczeń, ale formułuje również dalej idący zakaz - zaciągania zobowiązań do ich zbywania (np. zawierania umów sprzedaży czy darowizny wierzytelności odszkodowawczych).

rakter trwały. Wymóg trwałości stanu niemożliwości świadczenia, konsekwentnie formułowany na tle art. 387 k.c. ${ }^{19}$, nie wydaje się spełniony w omawianym tutaj przypadku. Brak wymagalności czy uznania roszczenia odszkodowawczego to stan, który może zmienić się w każdej chwili. Odrzucenie możliwości kwalifikowania umowy zobowiązującej do przelewu wierzytelności odszkodowawczych niemających cech określonych w art. 449 k.c. jako zobowiązującej do świadczenia niemożliwego nie powinno prowadzić do wniosku o ważności takiej umowy. Sądzę, że przeciwko takiemu wnioskowi przemawia jednoznacznie omówioną wyżej ratio legis art. 449 k.c.

Przyjęcie, że umowy zobowiązujące do przelewu wierzytelności odszkodowawczych niemających cech określonych w art. 449 k.c. pozostawałyby ważne, musiałoby oznaczać, iż z uwagi na ograniczenia płynące $z$ art. 449 k.c. - wbrew regule wynikającej

18 Co do sposobu definiowania tego rodzaju niemożliwości świadczenia zob. np. P. Machnikowski (w:) E. Łętowska (red.), System prawa prywatnego, t. 5, Warszawa 2013, s. 563.

19 Zamiast wielu zob. P. Machnikowski (w:) System prawa prywatnego, t. 5, dz. cyt., s. 565. nie skuteczności przelewu roszczeń odszkodowawczych niewymagalnych i nieuznanych przez dłużnika (niestwierdzonych wyrokiem) prowadziłoby do tego, że umowa zobowiązująca do ich przelewu w praktyce nigdy nie zostałaby wykonana. $Z$ uwagi na fakt, że ograniczenie skuteczności przelewu wynika z powszechnie obowiązującego przepisu prawa, dłużnik (zobowiązany do przelewu) nie może twierdzić, że niewykonanie umowy obligującej do przelewu (nieprzeniesienie roszczeń na nabywcę) nie jest spowodowane brakiem należytej staranności (zob. art. 472 k.c.). To z kolei oznacza, że ważnie zawarta umowa zobowiązująca do przelewu, niewykonana następnie z przyczyn, za które dłużnik ponosi odpowiedzialność, musiałaby narażać zbywcę na odpowiedzialność z tytułu niewykonania czy nienależytego wykonania zobowiązania (art. 471 i nast. k.c.). W jej ramach niedoszły nabywca wierzytelności odszkodowawczych mógłby dochodzić odszkodowania. Moim zdaniem w typowych przypadkach wysokość tego odszkodowania musiałaby odpowiadać co najmniej wartości nienabytej, a przez to niezrealizowanej wierzytelności odszkodowawczej, tzn. wartości odszkodowania, jakie należałoby się poszkodowanemu, a w razie sku- 
teczności przelewu - cesjonariuszowi ${ }^{20}$. Powstanie takiej odpowiedzialności zupełnie niweczyłoby cel ochronny art. 449 k.c. Trudno mówić o skuteczności takiej ochrony, skoro poszkodowany, wprawdzie zabezpieczony przed ryzykiem zbycia swojej wierzytelności odszkodowawczej poniżej wartości należnego mu odszkodowania, ryzykuje jednak koniecznością postać umowy między wierzycielem i dłużnikiem odszkodowawczym ${ }^{21}$.

Drogę do zbywalności wymagalnego roszczenia należącego do grupy roszczeń, których dotyczy art. 449 k.c., otwiera wyłącznie uznanie właściwe, tj. uznanie przyjmujące postać umowy między wierzycielem i dłużnikiem odszkodowawczym

\section{Drogę do zbywalności wymagalnego roszczenia należącego do grupy roszczeń, których dotyczy} art. 449 k.c., otwiera wyłącznie uznanie właściwe, tj. uznanie przyjmujące postać umowy między wierzycielem i dłużnikiem odszkodowawczym.

zapłaty jego równowartości tytułem odszkodowania za niewykonanie umowy, w ramach której sam otrzymał kwotę, która nie stanowi jego ekwiwalentu.

\section{Tylko uznanie właściwe?}

Przytoczona wyżej ratio legis art. 449 k.c. uzasadnia, moim zdaniem, wniosek, zgodnie z którym drogę do zbywalności wymagalnego roszczenia należącego do grupy roszczeń, których ten przepis dotyczy, otwiera wyłącznie uznanie właściwe, tj. uznanie przyjmujące

20 Por. trafne uwagi M. Krajewskiego (M. Krajewski (w:)

E. Łętowska (red.), System prawa prywatnego, t. 5, dz. cyt., s. 858, 912 oraz 917 i n.), który przyjmuje, że przy braku szczególnego uregulowania ograniczającego odpowiedzialność z tytułu niewykonania umowy przedwstępnej do ujemnego interesu umownego dłużnik odmawiający zawarcia umowy przyrzeczonej odpowiadałaby w granicach pozytywnego interesu umowy przyrzeczonej. Analogiczne wnioski nasuwają się w odniesieniu do skutków niewykonania stricte obligacyjnej umowy zobowiązującej do przelewu. Jej niewykonanie (tzn. brak przejścia wierzytelności na nabywcę) naraża dłużnika na odpowiedzialność za szkodę, której rozmiar kształtowany jest przede wszystkim przez wartość świadczenia, które nie weszło do majątku nabywcy z powodu braku uzyskania roszczenia o jego spełnienie.
Uznanie niewłaściwe, będące oświadczeniem wiedzy dłużnika, $z$ definicji nie może zawierać wiążącego określenia wysokości odszkodowania czy zadośćuczynienia, którego zapłaty dotyczy uznawany dług ${ }^{22}$. Określenie takie może być natomiast elementem uznania właściwego rozumianego jako umowa, w której dłużnik potwierdza istnienie swojego obowiązku, i zobowiązuje się do jego realizacji. Tylko uznanie właściwe, w którego treści sprecyzowano wysokość zadośćuczynienia czy odszkodowania (ustalono wysokość roszczenia), pozwala zrealizować cel w postaci eliminacji ryzyka pokrzywdzenia poszkodowanego wynikającego ze zbycia nieokreślonych co do wysokości roszczeń za kwotę niższą od sumy, na jaką okażą się ostatecznie opiewać ${ }^{23}$.

21 Co do powszechnie podzielanego w nauce sposobu rozumienia uznania właściwego jako umowy między wierzycielem a dłużnikiem zob. np. P. Machnikowski (w:) P. Machnikowski, E. Gniewek (red.), Kodeks cywilny. Komentarz, Warszawa 2017, s. 315.

22 Odmiennego zapatrywania zdaje się bronić A. Olejniczak (w:) Kodeks cywilny..., dz. cyt., s. 595.

23 Z. Masłowski (w:) Kodeks cywilny..., dz. cyt., s. 1131. 


\section{Tylko wymagalność?}

Artykuł 449 k.c. zakłada, że roszczenie odszkodowawcze należące do wskazanej w nim grupy staje się zbywalne jedynie wówczas, gdy jest wymagalne. Niekiedy przyjmuje się, że z uwagi na właściwość zobowiązania, którego uwzględnienie nakazuje art. 455 k.c., świadczenie polegające na naprawieniu szkody wyrządzonej czynem niedozwolonym powinno być spełnione niezwłocznie po wystąpieniu szkody. W myśl tego poglądu to właśnie ten moment wyznacza wymagalność omawianych roszczeń odszkodowawczych ${ }^{24}$. Jednak zgodnie $\mathrm{z}$ dominującym $\mathrm{w}$ doktrynie i orzecznictwie poglądem naprawienie szkody wyrządzonej deliktem, w tym zadośćuczynienie roszczeniom przewidzianym w art. 444-448 k.c., stanowi świadczenie bezterminowe. Wymagalność wspomnianych roszczeń następuje więc stosownie do art. 455 k.c. - w konsekwencji wezwania przez wierzyciela do spełnienia świadczenia i przypada niezwłocznie po takim wezwaniu ${ }^{25}$.

W typowych przypadkach uzależnienie możliwości zbycia roszczeń odszkodowawczych od ich wymagalności odpowiada ratio legis rozwiązania przewidzianego w art. 449 k.c. Niekiedy taki wniosek nie byłby jednak uprawniony. Chodzi o, nierzadkie w praktyce, sytuacje, gdy poszkodowany oraz osoba odpowiadająca za szkodę określili umownie, w treści ugody, termin zapłaty odszkodowania czy zadośćuczynienia. Abstra-

24 A. Olejniczak (w:) Kodeks cywilny..., dz. cyt., s. 594; por. Wyrok Sądu Najwyższego z dnia 21 maja 2003 r., IV CKN 378/01, OSP 2004, nr 4, poz. 55; podobnie, choć w węższym zakresie, w Wyroku Sądu Najwyższego z dnia 28 października 2016 r., I CSK 661/15, Legalis, gdzie przyjęto, że „jeżeli tylko poszkodowanemu dostępna jest informacja o zaistnieniu szkody i osobie odpowiedzialnej do jej naprawienia, roszczenie deliktowe staje się wymagalne niezwłocznie po powstaniu szkody, czyli zaistnieniu zdarzenia, z którego wynikł uszczerbek w majątku poszkodowanego".

25 Tak np. Z. Masłowski (w:) Kodeks cywilny..., dz. cyt., s. 1131; M. Zelek, Wymagalność pieniężnych roszczeń odszkodowawczych a możliwość żądania odsetek za opóźnienie, „Studia Prawa Prywatnego" 2017, nr 2, s. 7; P. Sobolewski (w:) Kodeks cywilny..., dz. cyt., s. 855; zob. też K. Mularski (w:) Kodeks cywilny..., dz. cyt., s. 1879; w orzecznictwie tak np. w Wyroku Sądu Najwyższego z dnia 9 marca 1973 r., I CR 55/73, Legalis oraz Wyroku Sądu Apelacyjnego we Wrocławiu z dnia 6 maja 2015 r., I ACa 245/15, Legalis. hując od pojawiających się w podobnych przypadkach wątpliwości związanych z przedawnieniem roszczeñ ${ }^{26}$, należy stwierdzić, że ugoda, w której określono termin zapłaty (harmonogram płatności częściami) odszkodowania czy zadośćuczynienia jest dopuszczalna i skutecznie wpływa na moment wymagalności roszczenia odszkodowawczego, który nastąpi wówczas po upływie terminu określonego w ugodzie ${ }^{27}$. Konsekwentne trzymanie się literalnej wykładni art. 449 k.c. musiałoby oznaczać, że poszkodowany, którego roszczenie zostało ustalone co do wysokości w treści uznania właściwego ( $z$ definicji będącego elementem ugody) nie może zbyć go w czasie między zawarciem ugody a upływem określonego w jej treści terminu zapłaty odszkodowania. Taka konkluzja nie odpowiadałaby przyjętej w tym opracowaniu ratio legis art. 449 k.c. Jako taka powinna być, moim zdaniem, odrzucona. Po zawarciu ugody nie występuje zagrożenie, przed którym art. 449 k.c. ma chronić poszkodowanego. Nie ma tu niebezpieczeństwa zbycia roszczenia za cenę znacznie niższą od kwoty należnego poszkodowanemu odszkodowania. Jest przy tym oczywiste, że termin zakreślony na spłatę odszkodowania nie pozostaje bez wpływu na wartość rynkową roszczenia odszkodowawczego. Im termin ten jest bardziej odległy, tym

26 Bieg przedawnienia roszczenia o naprawienie szkody wyrządzonej czynem niedozwolonym co do zasady rozpoczyna się w dniu, w którym poszkodowany dowiedział się albo przy zachowaniu należytej staranności mógł się dowiedzieć o szkodzie i o osobie obowiązanej do jej naprawienia. Określając termin zapłaty odszkodowania, w ugodzie strony wyznaczają więc moment wymagalności roszczenia, co do którego termin przedawnienia zaczął już biec, zanim ugoda została zawarta. W odniesieniu do tego rodzaju postanowień umownych często przyjmuje się, że nie wpływają one na bieg terminu przedawnienia, który należy uznać za nieprzerwany (zob. art. 119 k.c.). Jednocześnie uznaje się, że skutecznie modyfikują one chwilę wymagalności roszczenia, którego dotyczą. Zob. szerzej: P. Machnikowski (w:) Kodeks cywilny..., dz. cyt., s. 307; zob. też szczegółowe uwagi na ten temat: J. Kuźmicka-Sulikowska (w:) R. Strugała (red.), Wykładnia umów. Standardowe klauzule umowne. Komentarz praktyczny z przeglądem orzecznictwa, Warszawa 2018, s. 346 i n. oraz przytoczoną tam literaturę i orzecznictwo.

27 Por. Wyrok Sądu Najwyższego z dnia 28 października 2016 r., I CSK 661/15, Legalis. 
roszczenie takie staje się mniej warte. Poszkodowany może łatwo ocenić swoją sytuację i świadomie zdecydować, czy chce „czekać na wymagalność roszczenia”, czy raczej uzyskać pewną część odszkodowania (w postaci ceny za zbywaną wierzytelność) natychmiast. Sformułowane właśnie wnioski pozostają aktualne także w tych, o wiele rzadszych w praktyce przypadkach, gdy świadczenie odszkodowawcze (zadośćuczynienie) zostało zasądzone w wyroku, w którym sąd rozłożył je na raty w trybie art. $320 \mathrm{KPC}^{28}$. Rozkładając zasądzone świadczenie na raty, sąd w wyroku dokładnie określa wysokość poszczególnych rat oraz czas ich zapłaty. Do nastąpienia terminu ich zapłaty nie są one oczywiście wymagalne w rozumieniu art. 449 k.c. Także w tym
Biorąc pod uwagę argumenty sformułowane wyżej, sądzę, że art. 449 k.c. należy rozumieć w ten sposób, że wymagalność roszczenia jest warunkiem jego zbywalności tylko o tyle, o ile nie jest ona konsekwencją określenia terminu płatności odszkodowania lub zadośćuczynienia w treści czynności prawnej lub w wyroku sądowym. Innymi słowy, wymagalność stanowi przesłankę zbywalności tych roszczeń tylko wówczas, gdy świadczenie odszkodowawcze ma charakter bezterminowy, a wymagalność ta następuje po wezwaniu, o którym mowa w art. 455 k.c. Gdy strony zobowiązania odszkodowawczego (lub sąd w wyroku) "przekształcą" świadczenie odszkodowawcze w terminowe (określając termin płatności odszkodowania),

\section{Przepis art. 449 k.c. należy rozumieć w ten sposób, że} wspomniana $w$ jego treści wymagalność roszczenia jest warunkiem zbywalności tego roszczenia tylko o tyle,

\section{o ile nie jest ona konsekwencją określenia terminu} płatności odszkodowania lub zadośćuczynienia w treści czynności prawnej lub w wyroku sądowym.

przypadku, zgodnie $\mathrm{z}$ ratio legis tego uregulowania, należy jednak przyjąć, że roszczenie o świadczenie odszkodowawcze jako „przyznane prawomocnym orzeczeniem" (zob. art. 449 in fine k.c.) może zostać zbyte.

Przepis art. 449 k.c. należy rozumieć w ten sposób, że wspomniana w jego treści wymagalność roszczenia jest warunkiem zbywalności tego roszczenia tylko o tyle, o ile nie jest ona konsekwencją określenia terminu płatności odszkodowania lub zadośćuczynienia w treści czynności prawnej lub w wyroku sądowym.

28 Możliwość zastosowania art. 320 KPC jest wyłączona tylko o tyle, o ile dochodzone od pozwanego roszczenie pochodzi z czynu niedozwolonego popełnionego umyślnie, w zamiarze uzyskania korzyści majątkowej (zob. Wyrok Sądu Najwyższego z dnia 23 czerwca 1972 r., I CR 599/71, Legalis). warunku wymagalności się nie stosuje. Przepis art. 449 k.c. uwzględnia więc wyłącznie przypadki typowe, poza którymi o zbywalności roszczeń odszkodowawczych decyduje sam fakt ich uznania lub stwierdzenia wyrokiem, bez konieczności wystąpienia stanu wymagalności roszczenia.

Zaprezentowany wyżej pogląd nie może jednak być odniesiony do wszystkich roszczeń z art. 444-448 k.c. W literaturze trafnie przyjmuje się, że gdy chodzi o rentę, o której mowa w art. $444 \S$ czy $446 \S$ k.c. zbyciu mogą podlegać tylko roszczenia o poszczególne raty rentowe, których termin zapłaty już minął (które stały się wymagalne $)^{29}$. Zasadę tę należy uznać za

29 Na podstawie art. 190 KPC dopuszczalne jest, rzecz jasna, dochodzenie przyszłych powtarzających się świadczeń. 
bezwzględną. W związku z tym roszczenia rentowe, co do których termin ich płatności został określony w ugodzie czy wyroku, nie są zbywalne, dopóki nie nastąpi ich wymagalność.

\section{Podsumowanie}

Dotychczasowe uwagi pokazują, że celowościowa wykładnia art. 449 k.c. powoduje, że efektywnie chroni on potencjalnego cedenta przed zbyciem roszczeń odszkodowawczych za cenę rażąco niższą od wartości należnego mu odszkodowania. W zakresie jego zastosowania, to znaczy w zakresie szkody na osobie, zakaz zbywania roszczeń odszkodowawczych nie jest więc celowy jako narzędzie tak pojmowanej ochrony poszkodowanych będących potencjalnymi cedentami. Oznacza to, że art. 9 projektu Ustawy o świadczeniu usług w zakresie dochodzenia roszczeń odszkodowawczych wynikających z czynu niedozwolonego w kształcie zaproponowanym dotychczas należy ocenić negatywnie. Jest to jednoznaczne z koniecznością opowiedzenia się przeciwko wprowadzaniu zaproponowanej w nim regulacji. Uznanie art. 449 k.c. za wystarczający środek ochrony poszkodowanych w zakresie ich roszczeń o naprawienie szkód na osobie każe przyjąć, że jakakolwiek zmiana uregulowania dotyczącego dopuszczalności zbywania roszczeń odszkodowawczych mogłaby być celowa tylko o tyle, o ile jej rezultatem byłoby objęcie nim także szkód na mieniu. Także to rozwiązanie nie wydaje się jednak trafne. Nietrudno dostrzec, że w odniesieniu do szkody na mieniu - inaczej niż to ma miejsce w przypadku szkód na osobie - wartość uszczerbków, a zatem także należnego poszkodowanemu odszkodowania, jest dużo łatwiejsza do oszacowania. Gdy chodzi o szkodę na osobie, która ma charakter dużo mniej uchwytny, poszkodowany może mieć problem z realnym oszacowaniem wysokości zarówno szkody niemajątkowej, jak i majątkowej. Druga z nich (zasadni-

O wymagalności można mówić wyłącznie w odniesieniu do roszczeń o zapłatę poszczególnych rat rentowych, co do których minął już termin ich płatności. Tylko takie roszczenia mogą stać się zbywalne, zgodnie z regułą wyrażoną w art. 449 k.c. Zob. szerzej: M. Drela, Renta jako prawo podmiotowe prawa cywilnego (w:) M. Drela (red.), Renta w prawie polskim, Wrocław 2016, s. 22; G. Kozieł (w:) A. Kidyba (red.), Kodeks cywilny. Komentarz, t. 3, Warszawa 2014, s. 864. czo pojmowana jako ból fizyczny, cierpienia psychiczne, stres, dyskomfort itp.) jest z definicji trudna do określenia. Pierwsza - jako że w granicach przewidzianych w art. 444 k.c. może podlegać naprawieniu jako postać tzw. szkody przyszłej (np. niełatwe do oszacowania, nieponiesione jeszcze, przewidywane przyszłe wydatki na leczenie) - jest również niełatwa do oszacowania, zanim nie zapadnie wyrok zasądzający odszkodowanie. Takie trudności nie występują w przypadku szkody na mieniu. Te, przyjmujące zawsze postać szkód majątkowych, uszczerbki sprowadzają się do poniesionych już rzeczywiście wydatków na naprawę lub wymianę uszkodzonych składników mienia poszkodowanego. Ewentualnie polegają one na utracie na skutek czynu niedozwolonego wartości rynkowej składników mienia poszkodowanego. Jako takie szkody te mają charakter bardziej uchwytny. W ich zakresie poszkodowany będący potencjalnym cedentem roszczeń odszkodowawczych może łatwo ocenić, czy oferowana w zamian za zbycie roszczeń cena jest adekwatna do wartości należnego mu odszkodowania. $\mathrm{W}$ moim przekonaniu oznacza to, że rozszerzanie zakresu zastosowania art. 449 k.c. na szkody na mieniu nie jest konieczne. Trzeba podkreślić, że jakiekolwiek ograniczenie możliwości cesji roszczeń jest jednoznaczne z ograniczeniem swobody umów i jako takie wymaga silnych argumentów, które mogłyby być skutecznie przeciwstawione podstawowym racjom przemawiającym za swobodą umów. Zagrożenia związane z działalnością kancelarii odszkodowawczych nie dostarczają, moim zdaniem, takich argumentów.

\section{Bibliografia}

Drela M., Renta jako prawo podmiotowe prawa cywilnego (w:) M. Drela (red.), Renta w prawie polskim, Wrocław 2016.

Kozieł G. (w:) A. Kidyba (red.), Kodeks cywilny. Komentarz, t. 3, Warszawa 2014.

Krajewski M. (w:) E. Łętowska (red.), System prawa prywatnego, t. 5, Warszawa 2013.

Kuźmicka-Sulikowska J. (w:) R. Strugała (red.), Wykładnia umów. Standardowe klauzule umowne. Komentarz praktyczny z przeglądem orzecznictwa, Warszawa 2018.

Machnikowski P. (w:) E. Łętowska (red.), System prawa prywatnego, t. 5, Warszawa 2013.

Machnikowski P. (w:) P. Machnikowski, E. Gniewek (red.), Kodeks cywilny. Komentarz, Warszawa 2017. 
Masłowski Z. (w:) Z. Resich i in. (red.), Kodeks cywilny. Komentarz, t. 2, Warszawa 1972.

Mularski K. (w:) M. Gutowski (red.), Kodeks cywilny. Komentarz, t. 1, Warszawa 2016

Olejniczak A. (w:) A. Kidyba (red.), Kodeks cywilny. Komentarz, t. 3, Warszawa 2014.

Safjan M. (w:) K. Pietrzykowski (red.), Kodeks cywilny, t. 1: Komentarz. Art. 1-449 $9^{10}$, Warszawa 2015.

Sobolewski P. (w:) K. Osajda (red.), Kodeks cywilny. Komentarz, t. 3A, Warszawa 2018.
Szpunar A., O przejściu na spadkobierców roszczeń z tytułu zadośćuczynienia, „Rejent” 2002, nr 9.

Śmieja A. (w:) A. Olejniczak (red.), System prawa prywatnego, t. 6, Warszawa 2014.

Wałachowska M. (w:) M. Habdas, M. Fras (red.), Kodeks cywilny. Komentarz, t. 3, Warszawa 2018.

Zelek M., Wymagalność pieniężnych roszczeń odszkodowawczych a możliwość żądania odsetek za opóźnienie, „Studia Prawa Prywatnego" 2017, nr 2. 